\title{
Ráduly Zsuzsanna
}

(Budapest, Magyarország)

\section{AZ EMBERI KÜLSÖ ÁBRÁZOLÁSA A MAGYAR ÉS A LENGYEL FRAZEOLÓGIÁBAN (A NÖVÉNY- ÉS AZ ÁLLATVILÁG TÜKRÉBEN)}

\begin{abstract}
Every language is characterized by such phraseological units and metaphors that are in connection with both the plant and animal world. The main goal of this paper is the presentation of the humans external look in Polish and Hungarian phraseology. This analysis may be performed in several ways, however for the sake of this article the external human look is the only topic of investigation, which can be observed in most of the plants and animals comparisons.
\end{abstract}

Keywords: linguistic image of the world, animal and plant world, phraseology

Minden nyelvben találkozunk olyan frazeológiai kapcsolatokkal, metaforákkal, közmondásokkal stb., amelyekben a rögzült kép az emberi világfelfogást, világnézetet tükrözi. „A frazeologizmusok a világ interpretációjáról és az adott nyelvben rögzült emberi értékekről tanúskodnak. A frazeologizmusok olyan tulajdonságokat fejeznek ki, amelyeket relevánsnak lehet tekinteni az adott nyelv-, kultúrközösség számára. A lexikalizált frazeologizmusok korábbi világnézetet jeleznek, amely a régebbi VNyK-t tükrözi" (Bańczerowski 2008: 145). Ebböl következik, hogy mind a frazeologizmusok, mind a metaforák a valóság felfogásának egyik alapvető módjai is.

A növény- és állatnevek magas száma a magyar és a lengyel frazeológiában nem véletlen, hiszen az ember a környezetében lépten-nyomon kapcsolatba kerül a különböző növényekkel és állatokkal. Megfigyeli a növények növekedését, alakját, élvezi azt a hasznot, amit nyújtanak, megfigyeli az állatok külső tulajdonságait, viselkedésüket. Különösen falusi környezetben a növényzet és az állatvilág az embert körülvevő környezet elválaszthatatlan része. Mindezek alapját képezik a frazeologizmusok, szólások, közmondások kialakulásának, tehát az emberi külsőt ábrázoló kifejezések szemantikai mezejébe beletartozhatnak a növények, állatok, valamint az egyes állatok testrészeinek és a növények különböző részeinek nevei is.

Jelen tanulmány fö célja az emberi külső ábrázolásának bemutatása a magyar és a lengyel frazeológiában. Elemzésük több szempontból is lehetséges, de ebben a cikkben az emberi külső ábrázolását helyezzük előtérbe, amely leggyakrabban a növényekkel és állatokkal való összehasonlításokban figyelhető meg. 
A legszembetünőbb fizikai tulajdonság az ember magassága, ezt mindkét nyelvben különféle fafajtákkal hasonlítják össze, itt természetesen nyelvenként eltérések tapasztalhatók. Általában az adott területen honos $\boldsymbol{f a f a j t a ́ k ~ n e v e ́ v e l ~}$ találkozhatunk. A magyarban a magasságot a fenyöhöz - Hosszú, mint a fenyöfa, illetve a jegenyéhez - Sudár, mint a jegenye hasonlítják, a lengyelben pedig a nyírfához - Wysoki jak brzoza [Magas, mint a nyírfa] és a nyárfáhozRosty jak topola [Magas, mint a nyárfa], ami nem véletlen, hiszen a nyárfa nagyon magas, nagyon gyorsan növő fa.

A magyarban még előfordul a csalán - Olyan már, mint a magos csalán, ennek a lengyelben nincs megfelelöje.

A fák nevén kívül más magas növények nevei is - komló, borsó elöfordulnak az összehasonlításokban, pl. a magyarban a Termetes, mint a komlókaró 'magas, nyurga ember', a lengyelben pedig Wysoki jak chmielowa/grochowa tyka [Magas és sovány, mint a komló/borsókaró].

A termethez kapcsolódnak azok a szólások, amelyek a növekedés ütemére mutatnak. Mindkét nyelvben, ha valaki vagy valami gyorsan nö, a gombához hasonlítják Hamar nö, mint a gomba = Rośnie szybko jak grzyby; Nö (terem v. szapora), mint (eső után) a gomba = Wyrastać, jak grzyby po deszczu; Gombamódra szaporodik = Rozmnaża się jak grzyby stb.

A magyarban a gyors növekedést, amely általában gyerekre jellemzö, a kender növéséhez is hasonlítják, pl.: Nö, mint a kender.

A magassághoz mindkét nyelvben más, negatív tulajdonságokat is társíthatnak. Magyarban a hitványságot vagy az erőtlenséget a magassággal társítják, pl.: Rossz fü nagyra nö, melynek jelentése az, hogy a hitványabb szaporább a jóravalónál; a magas termetủ emberek gyakran nem érnek fel belső érték tekintetében az alacsonyakkal. A nagyra nőtt, haszontalan emberre pedig azt mondják, hogy A paréj nö a legnagyobbra.

A lengyelben pedig a magassághoz leggyakrabban a butaság társul, amelyet egyik esetben állathoz, a másikban növényhez hasonlítanak. Íme a példa: Wysoki jak brzoza, a glupi jak koza [Magas, mint a nyírfa, buta, mint a kecske], Wysoki jak topola, a glupi jak fasola [Magas, mint a nyárfa, buta, mint a bab].

Érdemes megfigyelni, hogy a lengyel nyelvben a magasság erővel is jár, amire a magyarban nincs példa. Chłop jak dąb [Legény, mint a tölgy], Silny/krzepki jak dąb [Erös, mint a tölgy] 'nagyon erös'. A magyar közmondás szerint nem a magas emberek az erősek, mert: Amely karó magasra nö, ritkán szokott erös lenni.

Magyar nyelvben a kistermetü személyt maghoz, makkhoz hasonlítják: Apró, mint a mustármag; Akkora, mint a tökmag; Makknyi, makk ember. Érdemes hozzátenni, hogy a szülők a kisgyermeküket tökmagnak nevezik.

A mag, makk és a bimbó lexéma más jellegü frazeológiai kapcsolatokban is szerepel: Kicsiny a mustármag, de nagy a fája; Magról kel a cserfa is; Makkból lesz a tölgy is. Ezek általában a növények fejlödésére utalnak, átvitt értelemben az emberre is vonatkoztathatjuk, hogyan lesz a kisgyerekből felnőtt: Kisded 
bimbóból lesz a fontos körte; Parányi bimbó, nagy gyümölcs; A terebélyes rózsák is apró bimbókból erednek stb.

A lengyel nyelvben azok a szókapcsolatok, amelyek egyik komponense mag, inkább pejoratív kicsengésüek, pl.: Dziadowskie, hyclowskie, sobacze, złodziejskie itp. nasienie [Koldus, sintér, kutya, tolvaj magja]; Jakie nasienie, taki też owoc [Amilyen mag, olyan a gyümölcs is], Jakie nasienie, takie korzenie [Amilyen a mag, olyan a gyökér] stb.

Egyes magyar kifejezések viszont arról tanúskodnak, hogy a növényneveken kívül az ember magasságát még állatnév is kifejezheti, bár ezek száma elenyésző. Az alacsony embert az ülö kutyához hasonlítják, illetve a tömegből kimagasló egyént a szamárhoz. Íme a példa: Akkora, mint a kutya ülve; Kilátszik, mint szamár a nyájból.

A következő kategória a karcsúság, amely általában pozitív jelentéstartalmú. Ebben az esetben feltétlenül szét kell választani a férfiakra és a nőkre vonatkozó hasonlatokat. A karcsú nőt mind a lengyelben, mind a magyarban egyrészt a nádszálhoz, másrészt állatokhoz (darázshoz és özhöz) hasonlítják. A vékony, karcsú férfiakat a nyárfához (bár találtunk példát, amelyben a szólás nőre vonatkozott), illetve spárgához hasonlítják. Íme a példák: Darázsderekú $=$ Cienka $w$ talii jak osa; Karcsú, mint az öz = Zgrabna jak sarenka; Karcsú, mint a nádszál = Smukty jak trzcina; Cienki jak szparag [Vékony, mint a spárga], Smukty/a jak topola [Sudár, mint a jegenye]. A magyar nyelvben a Karcsú, mint a retek 'vastag' kifejezés pedig éppen az ellenkezőjét jelenti.

Annak ellenére, hogy a soványság kategóriában, amely általában negatív jelentéstartalmú, teljes egyezést nem találunk a két nyelvben, mégis van hasonlóság a kifejezésekben, hiszen gyakori a karó, kóró, fahasáb, fadarab szavak előfordulása, így a magyarban a növénynevek közül az alábbiak fordulnak elö: Sovány, mint a kóró; Olyan (száraz), mint a kóró 'nagyon sovány, kiaszott ember', Olyan, mint a kopogó fa 'nagyon sovány', Sihár, szikár (száraz), mint a nád 'nagyon sovány, szikár ember', Sovány, mint a paszulykaró 'sovány és hórihorgas személy, különösen nő'.

A lengyelben is hasonló módon fejezik ki a soványságot: Chudy jak szczapa [Sovány, mint a fahasáb], Chudy jak patyk, tyka [Sovány, mint a fadarab, karó], Chudy jak wiór [Sovány, mint a forgács] 'nagyon sovány, túlzottan karcsú'.

A magas, sovány nőt a lengyel nyelvben úgy jellemzik, hogy: Sucha wierzba [Száraz füzfa], ami régi kifejezés; a sovány férfi pedig Wyglada jak szczypiorek [Úgy néz ki, mint a metélőhagyma].

Az összegyüjtött anyag azt mutatja, hogy a szóban forgó nyelvekben a soványság a következő állatokhoz illetve madarakhoz való összehasonlításokban is előfordul: Sovány/nyúzott, mint az agár; Olyan, mint az agár = Chudy, wyciagnięty jak chart; Olyan, mint a gebe csikó = Chudy jak szkapa; Olyan, mint a görény; Olyan sovány, mint a böregér; Olyan, mint a 
nyúzott macska; Olyan sovány, mint a téli nyúl; Olyan, mint a cinege; Olyan sovány, mint a szárcsa; Olyan, mint a giliszta; Olyan, mint a pióca stb.

Szembetűnő az a jellegzetesség, hogy a magyarok sokkal több állatot tekintenek tipikusan soványnak, ezért ennek a külső tulajdonságnak az ábrázolása több állatnévvel kerül kifejezésre.

A lengyelben viszont csak elenyésző azoknak a hasonlatoknak a száma, amely a soványságot az állatokhoz hasonlítja, pl. Wygladać jak szczur [Úgy néz ki, mint a patkány], Istna wydra [Tipikus vidra].

Kövérség kifejezésében, amely általában pejoratív jelentéstartalmú, a magyar és a lengyel nyelv igen sok hasonlóságot mutat, tehát a kövér férfit mindkét nyelvben a disznóhoz és a medvéhez hasonlítják. Érdemes hozzátenni, hogy a lengyel nyelvben az elhízott embert még a bikához vagy az elefánthoz hasonlítják, a magyarban pedig lúdhoz, juhászkutyához, tökhöz. Íme a példa: Kövér, mint a disznó = Ttusty, spasiony jak wieprz; Disznó = Wieprz; Mackó alkat = Miś; Kövér, mint a bika = Gruby byk; Vaskos, mint a bika = Tęgi byk; Gruby jak stoń [Kövér, mint az elefánt], Kövér, mint Márton lúdja, Karcsú, mint a juhászkutya, Kövér, mint a tök.

Az elhízott nőt mindkét nyelvben elég gyakran a tehénhez hasonlítják. A lengyel nyelvben még a nöstény elefánthoz is: Tehén = Krowa; Stonica [Nöstény elefánt].

A nők nagy méretü kebleit a tehén tőgyéhez [...] hasonlítjuk: Nagy tőgyei vannak - Ma duże wymiona. De a lengyel nyelvben a tacskó vagy spániel füleit [...] is használjuk ennek a testrésznek a jellemzésére: Uszy jamnika lub spaniela [Tacskó vagy spániel fülek]. Magyarul pedig a formás és méretes melleket a madarak begyéhez [...] hasonlítják: Bögyös csaj (Dziewońska-Kiss 2010: 75).

Érdekes, hogy mind a magyarban, mind a lengyelben a sovány embert gyakran a különböző halfajtákkal hasonlítják össze. Íme a példák: Sovány, mint a csuka; (Olyan) sovány, mint a kárász; Olyan sovány, mint a sügér; Sovány, mint a hering = Chudy jak śledź; Wygladać jak śledź wymokty [Úgy néz ki, mint az ázott hering], Wygladać jak śledź holenderski [Úgy néz ki, mint a holland hering]. A kövérséget viszont csak a magyar nyelvben, például: Kövér, mint a harcsa; Olyan kövér, mint a potyka. Hozzátehetjük, hogy a lengyel Gruba ryba kifejezés [Kövér hal] a befolyásos, fontos emberre utal.

Mint ismeretes, a szépség szimbóluma kizárólag a virág, föleg a rózsa; Szép, mint liliomok közt a piros rózsa; Szép, mint a pünkösdi rózsa; Sáron rózsája = Róża Saronu; Olyan a lány, mint a rózsa = Dziewczyna jak róża; Szép, friss, mint a rózsa $=$ Piękny, świeży jak róża.

A magyar nyelvben a csúnyaságot a lúd, a pulyka és a majom állatnév konnotálja, a lengyelben majmon kívül még varangyos béka is szerepel az összehasonlításokban. Ezeket a kifejezéseket főleg csúnya nőre vonatkoztatják, a csúnya férfit majomnak, csimpánznak illetve gorillának is szokás nevezni. 
Olyan, mint a lúd a hattyúk között; Szebb a páva, mint a pulyka; Ropucha [Varangyos béka], Majom = Matpa; Csimpánz = Szympans; Gorilla $=$ Goryl .

Lengyel nyelvhasználók a csúnyaságot még az alábbi módon is kifejezhetik: Mógtby go nad prosem postawić [Köles fölé lehetne állítani], Choć w konopiach postawić [Bár kender közé lehetne állítani], amelynek jelentése 'olyan csúnya, hogy még madárijesztő sem lehetne.

Mindkét nyelvben az átlagos, elgyötört, rosszul kinéző nőt egérhez és tyúkhoz hasonlítják: Szürke egérke = Szara myszka/Szara mycha; Olyan, mint az ázott tyúk = Wyglada jak zmokta kura; Úgy néz ki, mint a döglött tyúk = Wygladać jak zdechła kura.

Mind a magyar, mind a lengyel frazeológiában szép számban szerepelnek olyan kifejezések, amelyek az emberi arc formáját, jellegzetességeit ábrázolják. Például az az ember, akinek az arca hosszúkás formájú, mindkét nyelvben Lóarcú = Końska twarz, akinek csúnya az arca, az Majom arcú = Matpia twarz.

A furcsa, buta vagy bamba arckifejezést mindkét nyelvben a következőképpen fejezzük ki: Birkaképü = Barania mina; Disznóképü = Świński ryj/Swińska morda.

A vizsgált nyelvekben az arc színét a különböző gyümölcsök színeivel és virágokkal azonosítják, például: Úgy nyílik az orcája, mint a bazsarózsa; Piros, mint az alma = Czerwony jak jabtko; Piros, mint a rózsa = Czerowna jak róża; Az arca mint a rózsa = Policzki jak róże; Piros, mint a paradicsom = Czerwony jak pomidor; Olyan piros lett, mint a pipacs = Czerwony jak mak; Elvörösödött, mint a cékla = Czerwony jak burak; Hamvas, mint az öszibarack = Brzoskwiniowa cera; Ma policzki, usta jak jagoda [Az arca, szája, mint az áfonya], Buzia jak malina [Az arca, mint a málna], Zaczerwieniła się jak piwonia [Elvörösödött, mint a pünkösdi rózsa].

A sápadt arcszín jelölésére a tök és kukorica lexémák fordulnak elö: Olyan sápadt, mint a cseppentett tökmag; Szép, mint a tejbe tök; Sápadt, mint a kukoricamálé; Sárga, mint a tökvirág.

Néhány összehasonlításból világosan kitünik, hogy a nyelvhasználók az arc különböző részeit is a növényekkel illetve állatokkal asszociálják.

$\mathrm{Az}$ ember különösen nagy orrát a magyarban és a lengyelben is a krumplihoz és az uborkához hasonlítják. Az ember ferde orrát a magyarban éppúgy, mint a lengyelben a ragadozó madarak csőréhez hasonlítják, tehát mindkét nyelvben megvan a sas, kacsa és karvaly csőréhez való hasonlítás. A lengyelben ezen felül megtalálható még a héja is. Íme a példák: Krumpliorra van = Ma nos jak kartofel; Olyan az orra, mint a sós uborka $=$ Ma nos jak ogórek; Sasorrú = Orli nos; Karvaly orrú = Krogulczy nos; Kacsaorrú = Kaczkowaty nos/Kaczy nos; Jastrzębi nos [Sólyomorrú].

A vizsgált nyelvekben a fáradtságtól (vagy túlzott alkoholfogyasztástól) piros szemeket a (házi)nyúl szeméhez hasonlítják: Piros a szeme, mint a nyúlnak $=$ Oczy jak u królika, az apró szemeket pedig sértő módon a 
disznóéhoz - Disznószemü = świńskie oczka; świńskie ślepia . A meglepődést, csodálkozást tükröző szem viszont olyan, mint a bocié: Boci szemek - cielęce ślepia, a dülledt szem pedig olyan, mint a halé - Halszemü = Rybie oczy.

A lengyel nyelvben még a marha és a béka szemével való összehasonlításokat is találunk, például: Wołowe oczy [Marhaszem], Żabie oczy [Békaszem].

A magyar nyelvhasználók a széles emberi szájat a harcsa Olyan a szája, mint a harcsának/Harcsaszájú szájához hasonlítják a lengyelek pedig az uborkához Usta jak ogórki [A szája, mint az uborka]. Mindkét nyelvben a túlzottan nagyméretü emberi fogakat gyakran a lovak fogaihoz hasonlítják: Lófogú = Końskie zęby.

Az emberi haj ösz színét mindkét nyelvben ugyanúgy a galamb, a fekete színét pedig holló elnevezés konnotálja. Magyar kifejezésekben még a csóka madárnév is szerepel. A lengyelben vörös hajú embert a mókus, magyarban a róka elnevezés jelöli: Fekete, mint a csóka; Olyan, mint a csóka; Ösz, mint a galamb $=$ Siwy jak gołab/Być siwym jak gołabek; Hollófekete $=$ Czarny jak kruk/Krucze wtosy; Vörös, mint a róka = Rudy jak wiewiórka; Mind a magyarban, mind a lengyelben a hosszú, hátul összefogott női hajat lófaroknak nevezzük: Lófarok = Koński ogon. A rövid, tüskés hajat pedig a sünhöz hasonlítják: Süni haja van = Włosy na jeża.

A szörös férfit mindkét nyelvben a majommal azonosítjuk, a hegyes rövid szakállat pedig a kecske szakállával: Szörös, mint a majom = Zarośnięty jak goryl/matpa; Kecskeszakállú = Kozia bródka/Kozia broda .

A hosszú, karcsú nyakú nőt mindkét nyelvben hattyúval hasonlítják össze: lengyelben még gólya is szerepel az összehasonlításokban. Íme a példák: Hattyúnyaka van = Łabędzia szyja; Bocianowata szyja [Gólyanyaka van].

A magyarban a túl hosszú kezekre azt mondjuk, hogy Hosszú a keze, mint egy majomnak, lengyelben, hogy pók 'olyan hosszú a keze, mint a póknak'. Közös a két nyelvben, hogy a szép, kecses, hosszú, formás női lábat hasonlíthatjuk az özek vagy gazellák kecses lábához: Gazellalábú = Ma nogi jak sarna/gazela, a kevésbé szépeket a kacsáéhoz: Kacsalábú = Ma nogi jak kaczka. A lengyel nyelvben a hosszú és nagyon vékony lábakat még gólyalábnak is nevezik: Bocianie nogi/Nogi bocianowate [Gólyaláb].

Az összegyüjtött anyag elemzése az mutatja, hogy mind a magyar, mind a lengyel nyelv rendkívül gazdag az emberi külsőt ábrázoló frazeológiai kapcsolatokban. A nyelvi példák arra is utalnak, hogy a szóban forgó nyelvekben az axiológiai rendszer hasonló, ami egyáltalán nem meglepő, hiszen egymással szorosan összefüggő fogalmakról van szó.

Jelen tanulmány föképpen a két nyelvben meglévő hasonlóságokat szándékozta bemutatni. Természetesen vannak mindkét nyelvben olyan frazeológiai kapcsolatok is, amelyek csak az egyik nyelv sajátjai, tehát nincs ekvivalensük a másik nyelvben. A példaként felhozott frazeologizmusokban az a világkép tükröződik, amelyik jellemző az adott kultúrára, az adott nyelvre és társadalomra. 


\section{Irodalom}

Bańczerowski, J. (2008) A föld nyelvi képe a magyar nyelvben. // A világ nyelvi képe. A világ mint a valóság metaképe a nyelvben és a nyelvhasználatban. Budapest, 237-246.

Bańko, M (ed.) (2005) Wielki słownik frazeologiczny PWN z przysłowiami. Warszawa.

Bárdosi, V. (ed.) (2004) Magyar szólástár. Szólások, helyzetmondatok, közmondások értelmező szótára és fogalmi köri szótára. Budapest.

Bartmiński, J. (2006) Językowe podstawy obrazu świata. Lublin.

Dobrzyńska, T. (1994) Mówiąc przenośnie... studia o metaforze. Warszawa.

Dziewońska-Kiss D. (2010) Állatnevek és állati testrészek a lengyel és a magyar nyelvi minősítésben. In: Bárdosi V. (ed) Világkép a nyelvben és a nyelvhasználatban. Budapest, 69-77.

Krzyżanowski, J. (1972) Nowa księga przysłów polskich i wyrażeń przysłowiowych polskich. Warszawa.

Lakoff, G. - Johnson M. (1988) Metafory w naszym życiu. Warszawa.

Margalits E. (1995) Magyar közmondások és közmondásszerű szólások. Budapest.

O. Nagy G. (1966) Magyar szólások és közmondások. Budapest.

Pajdzińska, A. (2006) Studia frazeologiczne. Łask.

Rácz J. (2000) Állatnevek a botanikában. Magyar Nyelvőr, 124/3. 329-340.

Rácz J. (2005) Növényekben a béka. Magyar Nyelvőr, 129/2. 186-202.

Ráduly Zs. (2000) Nazwy zwierząt w wartościowaniu językowym. In: Polono hungarica. Budapest, 315-320.

Skorupka, S. (1977) Słownik frazeologiczny języka polskiego. Warszawa.

Szemerkényi Á. (2009) Szólások és közmondások. Budapest.

Szymaczak, M. (ed.) (1981) Słownik języka polskiego. Warszawa.

\section{Rövidítések és jelölések:}

$\mathrm{v}$. = vagy

VNyK = világ nyelvi kép

[] szó szerinti fordítás

= ekvivalens

" jelentése 